\title{
Public Libraries Respond to the COVID-19 Pandemic, Creating a New Service Model
}

\section{Jon Goddard}

During the COVID-19 pandemic, public libraries have demonstrated, in many ways, their value to their communities. They have enabled their patrons to not only resume their lives, but to help them learn and grow. Additionally, electronic resources offered to patrons through their library card have allowed people to be educated and entertained.

The credit must go to the librarians, who initially fueled, and have maintained this level of service by re-writing the rules-creating a new service model.

Once libraries closed, librarians promoted ebooks and other important platforms available to patrons with their library cards. The result: The checkout of ebooks, and the use of these platforms rose, exponentially.

Community engagement became completely virtual with librarians, and those who provide library programs to the public, providing services on platforms that they may or may not have heard of, such as Zoom and Discord.

As libraries re-opened, many offered real-time reference services, as well as seamless and contactless curbside service, providing a sense of control and continuity amongst the chaos.

\section{EXPONENTIAL INCREASES IN ELECTRONIC RESOURCE USAGE}

Overdrive, which is currently used by nearly $90 \%$ of public libraries in the United States to manage both ebook and audiobook collections, saw an exponential increase in its usage. Since the lockdown began in mid-March, the daily average for ebook checkouts have been consistently $52 \%$ above pre-COVID periods. Additionally, new users to the platform have been consistently double and triple 2019 highs. $^{1}$

Library staff have been helping readers during this time to ensure they obtain access with their devices. In Suffolk County, New York, where new patron registration to Overdrive is up $72 \%$ from last year (as of August 2020), there has been no shortage of requests for help. ${ }^{2}$

With kids being home from school and learning virtually, it is no surprise that ebook readership skyrocketed amongst YA and Juvenile readers with an $87 \%$ increase from last year. ${ }^{3}$ To help them with their homework and studies, families turned to online tutoring. In Suffolk County, New York, the usage of the Brainfuse online live tutoring service has been consistently up by nearly $50 \%$ during the school closures ${ }^{4}$ Gale, a Cengage company, which offers Miss Humblebee's Academy, a virtual learning program for preschoolers, saw its user sessions increase by $100 \%$ from the previous year. ${ }^{5}$

Jon Goddard (jgoddard@northshorepubliclibrary.org) is a Librarian at the North Shore Public Library, and a member of the ITAL Editorial Board. (C) 2020. 
Adults, also eager to learn new skills, took to online courses as well. Gale Courses saw a 50\% increase in enrollments from March-July from the previous year. Likewise, Gale Presents: Udemy, which offers on-demand video courses, saw just over 21,000 course enrollments from MarchJune. ${ }^{6}$

To help those who did not have sufficient broadband Wifi to use these necessary resources and platforms, many libraries left their Wifi on even when the building was closed to allow access to those in the vicinity of the building. In addition, many libraries purchased Wifi hotspots to lend to their patrons.

According to Pew Research, approximately $25 \%$ of households do not have a broadband internet connection at home. ${ }^{7}$ While public libraries cannot provide the only local solution to this gap, here are other steps libraries have been taking during the shutdown:

- Strengthening wireless signals so people can access wireless from outside library buildings.

- Hosting drive-up Wifi hotspot locations.

- Partnering with schools to obtain and distribute Wifi hotspots to families in need.

\section{COMMUNITY ENGAGEMENT - VIRTUALLY}

Community engagement has been vital since the COVID-19 lockdown. Both librarians and those who provide library programs to the public had to quickly adjust to the virtual world in which we were suddenly living.

Using a mixture of social media platforms, including Facebook Live and Stories, Discord, Instagram, YouTube, Zoom, and GoToMeeting, librarians flocked to the internet, providing a wide range of programming.

Even those libraries that did not previously have any virtual programs managed to very quickly provide quality programs to their patrons.

Virtual programming was not available at the San José Public Library (SJPL) prior to the shutdown. Librarians quickly started to move programs online, including story time, and created a program called Spring Into Reading, similar to the summer reading program, to continue to encourage families to read together. They also started a weekly recorded story time, so patrons could call the library and use their phones to hear a story. To date, SJPL has hosted over 2,000 virtual events since the lockdown began on March 17 th. $^{8}$

Some libraries, like the Oceanside Library in New York, were offering virtual programs before the pandemic. When the library closed on March 13, the team started planning to move completely virtual. Two days later, the library was offering four programs a day, including story times, book chats, and book clubs. By the end of the week, they were offering eight programs a day. ${ }^{9}$ In April, May, and June, they found book discussions and story times were the most popular programs. They then started to open their programs to people from out of state, partnering with other libraries. The result? Program attendance has increased and several Zoom meeting rooms have been maxed out. ${ }^{10}$

Through the lockdown, library patrons have been exercising, listening to concerts, taking virtual vacations, learning new skills, cooking, playing games, and reducing stress. This incredible 
adaption was only possible due to library worker's quick thinking and a never-ending determination to help.

\section{DELIVERING INFORMATION AND MATERIALS WITH A NEW SERVICE MODEL}

At the San Jose Public Library (SJPL), which has over 500,000 library members, library staff had to quickly shift to a new online reality just after the shutdown.

To help patrons get the most from their electronic resources, SJPL used LibAnswers to post FAQs and email responses to their issues and questions. When a librarian was available, patrons could use LibChat to ask questions in real-time.

Because no one was in the library buildings to answer phones, LibAnswers and LibChat became the only way the public could communicate with staff. Chat reference conversations increased by nearly $400 \%$-from approximately 40 chat sessions per day to 160 per day. The chat service was also made available in Spanish, Vietnamese, and Chinese.

When the library implemented its Express Pickup service, SJPL utilized the Spaces functionality in LibCal to allow patrons to create pickup appointments. When patrons arrived at the library for their appointment, the SMS functionality in LibAnswers allowed patrons to text staff upon arrival.

Through the City of San José's SJ Access initiative, which aims to help bridge the digital divide in the city, SJPL worked closely with other city departments, and the Santa Clara County Office of Education, to purchase approximately 16,000 high-speed AT\&T hotspots for students and the public. ${ }^{11}$

\section{Working Towards the New Normal}

The American Library Association (ALA) is committed to advocate strongly for libraries on several different fronts.

Thanks to thousands of advocate communications with Congress, libraries secured \$50 million for the Institute of Museum and Library Services (IMLS) in the Coronavirus Aid, Relief, and Economic Security (CARES) Act. This enabled libraries and museums to apply for grants during this time of need. ${ }^{12}$

In addition, the ALA is currently advocating for the passage of the Library Stabilization Fund Act (S.4181 / H.R.7486) to allow libraries to retain staff, maintain services, and safely keep communities connected and informed. The legislation calls for $\$ 2$ billion in emergency recovery funding for America's libraries through the Institute of Museum and Library Services (IMLS). ${ }^{13}$

While the ALA is rightly advocating for these emergency funds, public librarians and administrators should take advantage of this time to strategically review what has been put into place to react to the COVID-19 pandemic, and plan for the long term. While it is true that libraries are physical spaces, they are also technology-driven services for learning and connections for all ages. Additionally, they have shown that due to this new service model, access has exponentially expanded to new patrons, showing tremendous value when it comes to education and engagement. 
This new service model should be preserved. Programs that engage our communities should be both physical and virtual. Physical media and books should be provided both at the circulation desk and through a contactless service. Reference services should be provided both at the reference desk, and through chat reference services. This must be our new normal.

\section{ENDNOTES}

${ }^{1}$ David Burleigh, Director, Brand Marketing \& Communication at Overdrive, phone conversation with author, October 9, 2020.

${ }^{2}$ Maureen McDonald, Special Projects Supervisor at the Suffolk Cooperative Library System, phone conversation, September 14, 2020.

${ }^{3}$ Burleigh.

${ }^{4}$ McDonald.

${ }^{5}$ Kayla Siefker, Head of Media \& Public Relations at Gale, a Cengage Company, Brian Risse, VP of Sales - Public Libraries. Muna Sharif, Product Manager, Discovery \& Analytics, phone conversation with author, October 16, 2020.

${ }^{6}$ Siefker.

${ }^{7}$ Pew Research Center, “Internet/Broadband Fact Sheet," June 12, 2019, accessed October 13, 2020, https://www.pewresearch.org/internet/fact-sheet/internet-broadband/.

${ }^{8}$ Laurie Willis, Web Services at SJPL, Phone conversation with author, October 14, 2020.

${ }^{9}$ Erica Freudenberger, "Programming Through the Pandemic," Library Journal, May 22, 2020, https://www.libraryjournal.com/?detailStory=Programming-Through-the-Pandemic-covid$\underline{19}$.

${ }^{10}$ Tony Iovino, Assistant Director for Community Services at the Oceanside Library, phone conversation with author, October 19, 2020.

${ }^{11}$ Willis.

${ }^{12}$ American Library Association, "Advocacy \& Policy," accessed October 15, 2020, http://www.ala.org/tools/covid/advocacy-policy.

${ }^{13}$ Ibid. 